\title{
ECOLOGICAL EDUCATION AS THE MOST IMPORTANT FACTOR OF MORAL FORMATION OF THE PERSONALITY OF STUDENTS OF SPECIAL SCHOOLS
}

\author{
Dr Parida M. Pulatova
}

Phd, Professor, Department Of Oligophrenopedagogy Tashkent State Pedagogical University Tashkent, Uzbekistan

\section{ABSTRACT}

The article highlights information about the role of a special school in the formation of moral qualities of students with intellectual disabilities, about the attitude of children with intellectual disabilities to nature, about the relevance, important aspects, meaning, place of environmental education.

KEYWORDS:- Environmental education, special schools, personality, special pedagogy, inclusive education.

\section{INTRODUCTION}

Nowadays, the problem of environmental protection is extremely urgent and attracts more and more attention. Labor activity and the way of life of modern society have become a powerful transformative force that affects the biosphere and disrupts the course of its natural evolution. The way out of the ecological crisis, scientists say, is impossible by technical means. Environmental education is a necessary condition for overcoming the negative consequences of anthropogenic impact on the environment and a factor in the formation of the environmental culture of the individual as a regulator of relations in the "man - environment" system. Environmental education is recognized by the international environmental movement of teachers as the most important area of pedagogical research and improvement of educational systems.

\section{THE MAIN RESULTS AND FINDINGS}

Environmental education as a complex problem of our time has become the object of attention of philosophical and sociological studies that consider environmental problems as universal.

Ancient sources say that peoples and nations that lived in the East and in particular in Central Asia have long considered themselves part of their native nature and raised their descendants in a spirit of deep respect for it. Encyclopedic scholars and thinkers of the Uzbek people, which have a distant and rich history, in their works called for a careful and respectful attitude to nature and its riches, its preservation and enhancement. The rich heritage of our great thinkers for several hundred years has served as an example of imitation of them, educating descendants in the spirit of love for nature and 
CURRENT RESEARCH JOURNAL OF PEDAGOGICS 2(11): 126-129,

November 2021 DOI: https://doi.org/10.37547/pedagogics-crjp-02-11-23

ISSN 2767-3278

(C)2021 Master Journals

Crossref do: 81 Google

Accepted 25th November, 2021 \& Published 30 ${ }^{\text {th }}$ November, 2021

the environment. Various examples of oral folk art, priceless monuments of spiritual heritage, served and serve as a means of ecological and spiritual education of the younger generation (Avesto, Ibn Sina, Abu Rayhon Beruniy, Abu Nasr Farabi, etc.).

The problems of environmental education were the subject of research by A.N. Zakhlebny, I.D. Zvereva, B.G. Johansen, N.N. Moiseeva, I. T. Suravegina, A.P. Sidelkovsky E. Turdikulov, Sh. Avazova and others, who developed general theoretical and methodological aspects of environmental education of schoolchildren.

In pedagogical science, there are two different terms: "environmental education" and "environmental education". The first is impossible without the second, and therefore education should develop in the context of the second, especially since knowledge by itself does not yet determine the direction of human activity. The essence of environmental education and upbringing lies in the acquisition by each person of a sense of nature, the ability to delve into its world, in nothing irreplaceable value and beauty; understanding that nature is the basis of life and existence of all living things on earth; dialectical continuity and interdependence of nature and man.

In such conditions, environmental education acquires particular importance, which is considered by a number of scientists as the most important factor in the moral formation of a personality. According to I.A. Bondarenko, N.N. Dostovalova, M.S. Kagan, N.V. Kartomysheva, the upbringing of the younger generation with a high ecological culture will make it possible to overcome a number of negative phenomena in the life of society, harmonize human relations with other people, with nature, with oneself as a part of nature.

The goal of environmental education is the formation of moral and value attitudes towards nature and people, the ability to self-restraint, a sense of personal responsibility for the state of the environment, practical participation in the revival of the disturbed balance between man and nature.

Environmental education is an integral system that covers the entire life of a person, and should begin from early childhood, when the first foundations of the world outlook and moral value experience of interaction with the subjectnatural environment are laid. Insufficient stability of the positive and respectful attitude of children to nature is associated with little experience of communication with nature. This should become a need for children, a source of joy, continuous enrichment of them with new experiences.

A specific feature of the ecological education of students with developmental disabilities is direct contact with objects of nature, "live" communication with nature, which are part of the developing ecological environment in a special educational institution. Students of auxiliary schools can learn the natural connections of living organisms with the environment and understand the rules for communicating with living things, humanely, take care of nature. Acquaintance with nature makes it possible to visually show the dependences existing in the world of the relationship between the organism and the environment.

Along with this, children's interest and love for nature, observation, curiosity, and speech develop. The variety of forms, colors, nature influences the feelings of the child, teaches him to understand and appreciate the beautiful.

As the study of experience shows, in special schools for children with psychophysical developmental disorders, insufficient work is being done to study the rich ethnopedagogical heritage and culture of our people from an 
CURRENT RESEARCH JOURNAL OF PEDAGOGICS 2(11): 126-129,

November 2021 DOI: https://doi.org/10.37547/pedagogics-crjp-02-11-23

ISSN 2767-3278

(C)2021 Master Journals

Crossref doi) 81 Google

Accepted 25th November, 2021 \& Published 30 ${ }^{\text {th }}$ November, 2021

environmental point of view.

At the same time, the issue of the integral process of environmental education, based on the teaching of natural and humanitarian subjects in special schools for mentally retarded children, remains unexplored.

Thus, there is a contradiction between the objectively increased demands of society for the ecological education of children in general and, in particular, children with intellectual disabilities in the ecological and pedagogical work of special institutions, and the insufficient theoretical elaboration of the issue.

With this in mind, the problem of research was determined: under what pedagogical conditions is it possible to educate children with special needs in the environment. The solution to this problem was the goal of the study.

The subject of the research was the process of environmental education of mentally retarded students in grades 5-9 of special schools in the process of teaching natural and humanitarian subjects. Based on the purpose of the study, the analysis of psychological and pedagogical literature, the practice of the work of special institutions, a hypothesis was formulated that the ecological education of mentally retarded students will be formed with the purposeful teaching of natural and humanitarian subjects, implemented on the basis of:

- Organization of a holistic ecologicalpedagogical process in the classroom and outside the classroom activities of students, taking into account the integration of its cognitive, emotional orientation;

- The formation of a system of knowledge about nature, including ideas about the variety of environmental factors, the connection of people with the environment will allow the formation of social adaptation and interaction with the external environment, their adaptability to life;

- Inclusion of students of special schools in environmentally oriented practical activities to create optimal conditions for normal life. In accordance with the problem, purpose and subject of the study, the following tasks were set:

1. To identify the level of environmental knowledge and attitudes towards them among students of special schools.

2. Develop an accessible system of environmental knowledge for mentally retarded students.

3. To determine and experimentally substantiate the pedagogical conditions of environmental education in the process of teaching geography and natural science. Based on the results of the study, develop a scientific and methodological complex for teachers of defectologists and mentally retarded students. The study was carried out in three stages. The experimental base was special auxiliary schools, boarding schools No. 103, 105 of the city of Tashkent.

\section{Conclusion}

As a result of the study, the need for environmental education in the process of teaching school subjects has been theoretically and experimentally proved. The educational correctional and developmental possibilities of creating an ecological environment in a special educational institution, which allows accumulating emotional and sensory experience in interaction with wildlife, are shown. The pedagogical conditions of ecological education of mentally retarded students are determined. Programs in geography and natural history have been developed for grades 5-9. Purposeful 
CURRENT RESEARCH JOURNAL OF PEDAGOGICS 2(11): 126-129,

November 2021 DOI: https://doi.org/10.37547/pedagogics-crjp-02-11-23

ISSN 2767-3278

(C)2021 Master Journals

Crossref do: 81 Google

Accepted 25th November, 2021 \& Published 30 ${ }^{\text {th }}$ November, 2021

greening of teaching contributed to the fact that in the content of each lesson, information of an ethnopedagogical nature was introduced (proverbs, sayings, excerpts from hadiths, folk traditions, aphorisms, the heritage of oriental thinkers) associated with a respectful attitude towards nature and its wealth.

The success of the ecological education of senior students of the special school was largely ensured by a close connection with local history material. Therefore, extracurricular activities were carried out relying on centuries-old national traditions and customs of our people. Students of special schools got to know their native nature in detail and in detail. take an active part in the events held in the mahalla for the protection of nature and the environment. For example, participation in hashars for landscaping and landscaping adjacent to the place of residence, in holding the holidays "Sun, air and water are our best friends!" , "Young Ecologists", "Green World", "Navruz", "Harvest Festival", "My Mahalla" and others.

And so, the ecological education of senior students of special schools was carried out both in classroom and in extracurricular and extracurricular activities, relying on national traditions and national values.

\section{REFERENCES}

1. Zakhlebny A.N. School and problems of nature protection. -M.,: Pedagogy, 1981- p. 6-48

2. Zvereva I. D. General methods of teaching biology.-M .: Education, 1985.-191 p.

3. Edited by ID Zverev, T.I. Surovegina. -M .: Education, 1984-160 p..

4. Stars of spirituality.- T .: "Science" -2000.
5. Pultatova P.M. - Scientific and methodological bases of environmental education in special schools - $\mathrm{T}$.: "Science and Technology" - 2008.

6. Dalibaevna, N. D. (2021). GENDER EQUALITY IS ONE OF THE REQUIREMENTS OF A DEVELOPED SOCIETY. CURRENT RESEARCH JOURNAL OF HISTORY (2767-472X), 2(06), 82-85.

7. Isakova, A. (2017). The concepts of formation of ecological education. International Multidisciplinary Scientific GeoConference: SGEM, 17, 211-217.

8. DJURAEVA, N. (2021). ATTITUDE TO WOMEN IN UZBEKISTAN IN PUBLIC POLICY AND STRATEGY. Journal of Information and Computer Science, (1), 52-56.

9. Anufrieva, N. I., Volkov, L. V., Aralova, E. V., Kolomyts, O. G., \& Myagkova, E. V. (2020). Environmental education: Nurturing of the humanistic orientation of a personality. Universal Journal of Educational Research, 8(11), 5529-5535.

10. Vinogradova, G. A., Akhmadieva, R. S., Konovalova, V. M., Spirina, E. V., Kalugina, O. A., Erdyneeva, K. G., ... \& Mashkin, N. A. (2018). Releasers as factor of student ecological focus formation. Ekoloji, 27(106), 1409-1415.

11. DJURAEVA, N. (2021). ATTITUDE TO WOMEN IN UZBEKISTAN IN PUBLIC POLICY AND STRATEGY. Journal of Information and Computer Science, (1), 52-56. 